THE EDUCATION OF ACQUISITIONS LIBRARIANS

\title{
ON FORMALIZING ACQUISITIONS TRAINING
}

\author{
SARA C. HEITSHU \\ University of Michigan Library \\ CLR Intern at University of Connecticut Library \\ Storrs, Connecticut 06268
}

There has been general agreement among acquisitions librarians, book dealers and publishers, and library educators that library schools have done little or nothing to prepare their students to fill positions in library acquisitions departments. An informal poll of practicing acquisitions librarians would probably reveal that the majority of them learned on the job, their prime sources of information having been other acquisitions librarians, longtime members of their staffs, and the book dealers and publishers' representatives with whom they did business. A few have been lucky enough to have had prior experience as assistants in acquisitions departments, but the number of these is probably small. Most libraries seem to employ only one professional in acquisitions, and that one librarian must seek advice on acquisitions outside of her home institution. The only other way in which library staff have become knowledgeable about acquisitions has been through employment in the book trade.

Fortunately, I see definite signs that the informal educational arrangements of the past are being replaced both in library schools and among practicing librarians. To illustrate the improved opportunities for students I shall describe the program at the University of Michigan School of Library Science, and the cooperation which exists between the School and the University Library, since I am familiar with this program. The variety of experiences open to the practitioner will also be drawn from personal knowledge since this is an informal survey and not a research paper.

At Michigan, the subject of acquisitions is introduced to students in a core course, Building Library Collections. After students have taken this course, they may elect a course devoted to technical services developed by Constance Rinehart and Rosemary Magrill. One major portion of the course covers pre-order searching and acquisitions, and students who are interested in exploring the topic further may write the required term paper on some aspect of acquisitions. The Book Purchasing Division of the University of Michigan Library has always been involved in the acquisitions section of the course by giving tours of the division and introductions to the automated order system. Individual staff members also aid students whose term papers deal with some aspect of acquisitions or automation. During the past summer the tour of the division was made 
into a slide tape show in order to provide an additional format for an unusually large summer term class.

A student interested in still more exposure to technical services work may also apply for the semester-long technical services intern program. The Catalog Maintenance Division of the University Library coordinates the intensive lecture/tour through Technical Services, and trains the interns to work in Catalog Maintenance helping to staff the busy catalog information desk in the Graduate Library. Each week the interns spend an hour and a half to two hours in a different unit of Technical Services with staff members who describe their role in the technical processing operation in detail. Each unit of work is accompanied by a list of suggested readings made up by the staff of that unit and the Catalog Maintenance staff member in charge of the interns.

The University of Michigan Library School is also fortunate to be able to offer a six weeks summer internship with a Michigan book dealer. Although no one has elected to participate in this program yet, it promises to be ideal for the student who is interested in a career in acquisitions.

Nearly everyone who is interested in library education agrees that practical experience is invaluable for students, but is difficult to provide. The intern program just described reaches only two students per semester, and it is not offered every semester. Similar programs in the reference departments of the Graduate and Undergraduate Libraries also must severely limit the number of interns that can be successfully taught and trained to serve as reference assistants in a semester.

An older program which provides a small number of students with unique job experience is the Graduate Student Staff Assistant program, jointly sponsored by the School of Library Science and the University Library. Under this program, outstanding candidates who have demonstrated financial need are given a chance to work their way through school by filling positions in the University Library which have been designated as GSSA positions. These positions are actually clerical jobs which have been converted by a library department or branch from regular 40 hour a week jobs to 30 hour a week appointments. The GSSAs, as they are called, are selected by supervisors from the applicant pool determined by the Library School. They receive a regular salary and benefits from the University Library, and tuition to cover a reduced course load from the Library School. Most students take two to two and a half years to finish their degree in this manner. The Book Purchasing Division has participated wholeheartedly in this program for a number of years, and this past summer increased its GSSA position from one to two.

While this program offers great benefits to students, it can present certain problems for the University Library. Converting a 40 hour a week clerical position to only 30 hours a week in order to fill it with a GSSA can be very difficult for many busy divisions and branch libraries to justify. Also no matter how eager, dedicated, and talented GSSAs may be, they do eventually receive their library degrees (usually when backlogs seem the largest) and move on, leaving the unit with the task of selecting and training replacements, who in most cases are available only at the beginning of certain terms during the academic year. In Book Purchasing, the calibre of the students hired and the pleasure of working with them has more than compensated for any inconvenience. It also important to remember that, unlike the internships, this program is not intended to provide a pre-professional experience. Although the jobs filled by GSSAs are clerical in nature, in Book Purchasing a real effort has been made to introduce the GSSAs to the professional activities of librarians in addition to the day to day work of a large acquisitions department.

GSSAs are not only student employees in the Library, of course. The Library School also provides the University Library with a pool of students willing to perform a wide variety of tasks as hourly workers in the library system in order to gain some practical experience before they seek their first professional position. Book Purchasing has also had excellent luck with these students due in part to their willingness and in part to the indepth training which they are given. The time spent in acquainting student employees not just with the department but also with the whole 
technical services work flow pays off in increased awareness of their own importance in the scheme of things, and encourages them to consider other career possibilities besides the familiar and ubiquitous reference positions.

If all library schools and their university libraries were offering programs such as the University of Michigan's, and many are, one might be tempted to think that the job of educating for work in acquisitions is being done. But as a practitioner it is impossible for me to ignore the needs of myself and others currently working in acquisitions, for the field, like all aspects of librarianship, is constantly changing. We librarians cannot afford to fall behind in our knowledge in a multitude of areas-automation, publishing, book selection, approval plans and blanket orders, names and statuses of book and serial vendors, budgeting and allocation techniques, OP buying, and exchange rates. Fortunately, my personal experience leads me to believe that we are looking after our own continuing education quite adequately in a wide variety of ways on national, regional and local levels.

On the national level the committees and discussion groups of the RTSD Resources Section of ALA do an excellent job on behalf of acquisitions librarians. And these groups are not just aimed at the library audience, but are designed to involve publishers and book and serial vendors as well. One of the most notable committees is the Bookdealer-Library Relations Committee, which has published several useful monographs in its Acquisitions Guidelines Series, and which has been instrumental in educating us about publishers who may be misusing prepayment plans. The Committee's practical advice on how to deal with such unscrupulous businesses has hopefully saved some of us some money. The Acquisition of Library Materials Discussion Group and the newly formed Bookdealers' Discussion Group discuss topics of interest to acquisitions personnel at every ALA meeting. The exchange of information in these informal sessions gives students, practitioners, dealers, and publishers a chance to learn.

The list of national and regional programs and conferences on acquisitions and selection is impressive, but many librarians, whose institutions have little or no travel funds available, must rely on more local efforts to keep informed. Two excellent example of these efforts are PAIN (Philadelphia Acquisitions Information Network) and PLAIN (Piedmont Library Acquisitions Information Network). Both groups were formed by area librarians in order to facilitate the exchange of information among themselves, and to bring in outside speakers to their meetings whenever possible. To start and maintain such a group can be costly in initial time and effort, but it can be very satisfying and informative for everyone who gets involved.

In this informal paper 1 have tried to cover some of the educational efforts in acquisitions of which I am aware. Hopefully, these efforts are typical of those in other parts of the country, and we will not be so ready to joke about our lack of education in acquisitions in the 1980s. The opportunities are there and are improving. We must take advantage of them, and we must see to it that we are doing our part to provide new opportunities for ourselves to learn and to train the next generation of acquisitions specialists. 